\title{
Corona virus lowers hemoglobin more in severe infection than mild COVID-19 infection.
}

1. MBBS, M.Phil (Pharmacology) Associate Professor Pharmacology Rawal Institute of Health Sciences Islamabad.

2. MBBS, M.Phil (Physiology) Assistant Professor Physiology Ameer-ul-din Medical College Lahore.

3. MBBS, M.Phil (Pharmacology) Associate Professor Pharmacology Rawal Institute of Health Sciences Islamabad.

4. MBBS, M.Phil (Biochemistry) Assistant Professor Biochemistry Quetta Institute of Medical Sciences.

5. MBBS, M.Phil (Pathology) Assistant Professor Pathology Rawal Institute of Health Sciences Islamabad.

6. MBBS, FCPS

Consultant Ophthalmologist Mughal Eye Hospital Lahore.

Correspondence Address:

Dr. Zunnera Rashid Chaudhry Department of Pharmacology Rawal institute of Health Science Islamabad.

zunnerach@gmail.com

Article received on: 12/04/2021

Accepted for publication $15 / 06 / 2021$

\section{Zunnera Rashid Chaudhry1, Sana Rasheed ${ }^{2}$, Sabeen Shakir ${ }^{3}$, Erum Rashid ${ }^{4}$, Maliha Ansari ${ }^{5}$,} Faiza Rasheed ${ }^{6}$

ABSTRACT... Objectives: To study the effect of corona virus on blood hemoglobin and the changes this virus causes on hemoglobin in COVID-19 infected patients. Study Design: Observational study. Settings: Rawal institute of Health Sciences and Pakistan Institute of Medical Sciences, Islamabad. Period: Feb 2021 to April 2021. Material \& Methods: Total 100 adult patients were included all were suffering from corona virus infection. COVID-19 infected patients belonging to both genders with no other cause of anemia were selected and all adult patients in which anemia was due to diseases other than corona infection were excluded. The blood samples of COVID-19 infected patients was taken in 5cc syringe and was send to the laboratory of Rawal Institute Of Health Sciences Islamabad for hemoglobin estimation. Blood heamoglobin $(\mathrm{Hb})$ at the time of admission was recorded. Changes in their blood $\mathrm{Hb}$ was noted. Data was be entered into SPSS version 23, normality of data was checked. For nonnormally distributed data kruskal wallis and Mann whitney $U$ test was applied and for normally distributed data Anova and post hoc was used. Spearsman correlation was used to correlate non distributed data and Pearson's correlation was used for normally distributed data. Results: 100 adult patients were divided in two groups. Group I with mild symptoms of corona virus and group II with severe symptoms of corona virus. Patients with mild corona symptoms their blood hemoglobin level was $12.2 \mathrm{~g} / \mathrm{dl}$ and those with severe corona symptoms their blood hemoglobin level was $10.0 \mathrm{~g} / \mathrm{dl}$. Conclusion: It was observed that patients suffering from severe disease of corona COVID-19 had reduced hemoglobin levels than those suffering from milder form of disease, thus confirming that corona virus effects the hemoglobin level and reduces its serum value causing anemia leading to complication of disease.

Key words: $\quad$ Corona Virus, Hemoglobin, Reduced, Severe Infection.

Article Citation: Chaudhry ZR, Rasheed S, Shakir S, Rashid E, Ansari M, Rasheed F. Corona virus lowers hemoglobin more in severe infection than mild COVID-19 infection. Professional Med J 2021; 28(8):1211-1214. https://doi.org/10.29309/TPMJ/2021.28.08.6523

\section{INTRODUCTION}

(COVID-19) corona virus disease a global pandemic related to respiratory tract infection, with symptoms like common cold, now causing multiple organ sepsis Patients with corona infection having low hemoglobin are immune compromised and can rapidly suffer from other infections. This study is conducted to see the changes in blood hemoglobin caused by corona virus. COVID-19 is transmitted by three main routes, droplets transmission, contact transmission, aerosol transmission. ${ }^{1}$ Coronavirus after recognizing and binding to ACE2 host receptor, enters the host cell. ${ }^{2}$ The mucosal cells in throat, conjunctiva, nasal cavity and mouth are infected by the virus for replicating, virus enters the lungs causing fever, cough. ${ }^{2}$ Corona virus a positive RNA strand produces cytokines and chemokines. causing fever, damage to lungs and cough. ${ }^{3}$ Hemoglobin is a red blood cell protein with two $\alpha$ - and $\beta$-subunits and embedded heme ${ }^{4}$ corona requires porphryrins for its replication and survival, in hemoglobin the porphyrin is present in excessive amount, corona attacks the hemoglobin to get porphyrin, it attacks beta -1 chain of hemoglobin and catches the porphyrin, damages hemoglobin and it losses its ability to carry and deliver oxygen. ${ }^{5} \mathrm{COVID} \square 19$ patients with anemia exhibit severe inflammation response. Including poorer lung function, more serious myocardial injury and renal dysfunction. ${ }^{6}$ Corona virus attacks the red blood cell hemoglobin 
molecule, by interacting with receptors located on blood cell resulting in damage to hemoglobin, and produces hypoxia. ${ }^{7}$ Corona virus by blood reaches the sites where ACE2 receptors are present on heart, brain, kidney, vascular smooth muscle, and skeletal muscles. Damages the cell causing increased production of lactate which further effect the oxygen carrying ability of erythrocytes leading to tissue hypoxic. Therefore, the musculoskeletal system can also undergo infection and patients feel aches and pain in muscles and body. ${ }^{8}$ Reduced hemoglobin is seen more in severe form of disorder of disease and reduction in hemoglobin level is less in mild form of disorder of disease. ${ }^{9}$

\section{MATERIAL \& METHODS}

This experimental study was carried out in Rawal Institute of Health Sciences Islamabad. In this we divided the patients into two groups. Group 1 with mild corona symptoms and Group II with severe corona symptoms. Blood was taken in 5 cc syringe and was send to laboratory for hemoglobin estimation. Serum hemoglobin value of both types of patients was noted. Data was entered in SPSS version 23 and result was recorded.

\section{RESULT}

Group-I: All patients with mild symptoms of corona virus, their blood hemoglobin was taken in $5 \mathrm{cc}$ syringe and recorded at the time of admission.

Group-II: All patients with severe symptoms of corona virus, their blood hemoglobin was taken in 5cc syringe and recoreded at the time of admission.

\begin{tabular}{|l|c|c|c|}
\hline Parameter & $\begin{array}{c}\text { Mean SD } \\
\text { Group I } \\
(\mathbf{n = 5 0 )}\end{array}$ & $\begin{array}{c}\text { Mean SD } \\
\text { Group II } \\
(\mathbf{n = 5 0 )}\end{array}$ & P-Value \\
\hline $\mathrm{Hb} \mathrm{g/dl}$ & $12.2 \pm 1.3$ & $10.0 \pm 1.6$ & 0.00 \\
\hline
\end{tabular}

Table-I. Mean and Standard deviation of group I and II.

Patients with mild corona symptoms their blood hemoglobin level is $12.2 \mathrm{~g} / \mathrm{dl}$ and those with severe corona symptoms their blood hemoglobin level is $10.0 \mathrm{~g} / \mathrm{dl}$. There is $2.2 \mathrm{~g} / \mathrm{dl}$ difference in the hemoglobin of severely infected patients.

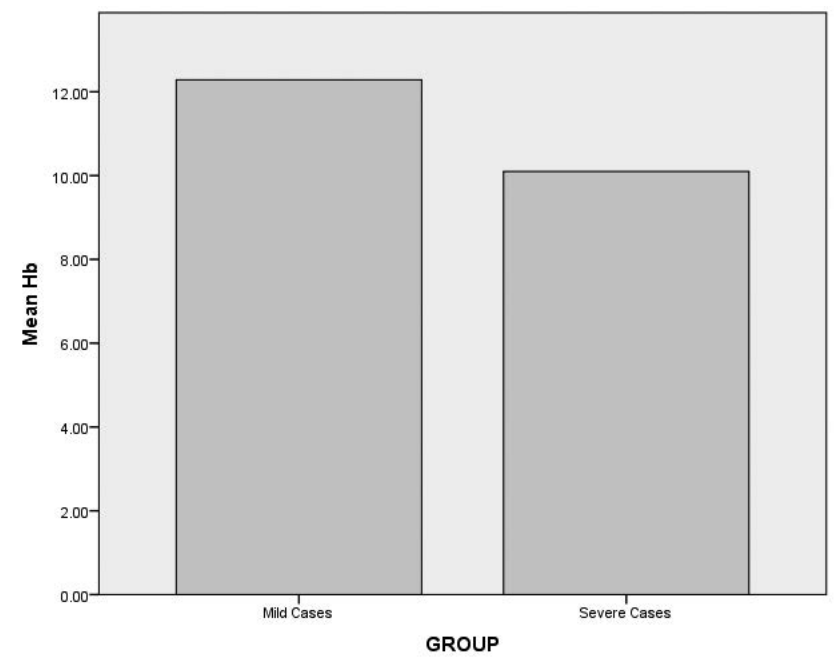

Figure-1. Bar graph of Group I (mild case) and II (severe case) with $\mathrm{Hb}$ value.

\section{DISCUSSION}

In our study we have seen that all the patients with severe symptoms of corona virus including fever, flu, cough, pneumonia, vomiting, diarrhea, loss of taste and smell their hemoglobin level was less as compared to patients with mild symptoms. We have seen that patients with severe corona infection their blood hemoglobin is $2.2 \mathrm{~g} / \mathrm{dl}$ less than those with mild infection. We can say there is $4.4 \%$ reduction in blood $\mathrm{Hb}$ level of patients with severe corona infections. Anai M 2021 conducted the research on hemoglobin level on COVID-19 infected patients and concluded that there is low hemoglobin level after severe corona infection and after pneumonia, this decrease hemoglobin further worsen the respiratory infection in corona patients ${ }^{9}$ Nobrega F et. al 2020 suggested that new coronavirus has ability to act on the hemoglobin beta chain and has potential to code proteins, this causes oxygen transport capacity of hemoglobin to be lowered contributing to hypoxia thus worsening the condition. ${ }^{10}$ In hemoglobin considering the structure of heme, is a combination of porphyrin with iron, porphyrin is ring like organic compound to which iron is attached. This iron atom attaches with oxygen reversibly and delivers oxygen. Liu W 2020. Conducted the research on Corona virus and concluded that this virus binds to hemoglobin beta -1 chain through surface glycoprotein. It 
inhibits heme metabolism by separating the iron component from porphyrin leading to formation of porphyrin alone. Iron accumulate in body in excessive amount causing inflammation and increase in C-reactive protein. ${ }^{11}$ This causes further stress on corona patients. Virus attacks more to deoxyhemoglobin, interfers with normal heme anabolic pathway, lowers the level of hemoglobin carrying oxygen, producing coagulation reaction and symptoms of respiratory distress. ${ }^{11}$

John Paul Graff, in 2020 in a case study said that corona virus acts on the bone marrow. Lab result showed Most of RBCs were of normal shape and size but in reduced number representing (normocytic anemia), few immature RBCs (nucleated), some with different sizes (anisocytosis) were seen, tear-drop shaped cells dacrocytes were rarely seen. ${ }^{12}$ In severe corona infection there is more severe anemia, this corona virus acts on the bone marrow stromal cells and the blood cells by production of auto antibodies and induction of immune complexes. ${ }^{13}$ Hariyanto Tl et.al 2020 said that identification of risk factors and its relation with severe disease is important for health. One such risk factor is anemia and it was seen that patient with anemia have the higher incidence of getting infected with corona virus. ${ }^{14}$ In our research we have seen that corona virus damages the red blood cells and lowers the hemoglobin. Lippi G 2019 suggested that there was great reduction in the hemoglobin levels of COVID-19 patients suffering from the worst form of disease than with those with less severe disease. ${ }^{15}$ These studies were conducted outside Pakistan. We have conducted this study in Pakistan and came to the conclusion that corona virus lowers the hemoglobin level in human irrespective of the place and environment.

\section{CONCLUSION}

Patients with severe corona infection have lower hemoglobin than those with mild COVID-19 infection. Corona attacks and damages the RBCs, effects the cells in bone marrow leading to damaged red blood cells and reduced hemoglobin level.

Copyright@ 15 June, 2021.

\section{REFERENCES}

1. National Health Commission of People's Republic of China. Pneumonia diagnosis and treatment of 2019nCoV infection from Chinese NHC and CDC 2020.http:// www.nhc.gov.cn.

2. Li H, Wang Y, Ji M, Pei F, Zhao Q, Zhou Y, Hong Y, Han S, Wang J, Wang Q, Li Q. Transmission routes analysis of SARS-CoV-2: A systematic review and case report. Frontiers in cell and developmental biology. $2020 \mathrm{Jul}$ 10; 8:618.

3. De Wit E, Van Doremalen N, Falzarano D, Munster VJ. SARS and MERS: Recent insights into emerging coronaviruses. Nature Reviews Microbiology. 2016 Aug; 14(8):523.

4. Ahmed $\mathrm{MH}$, Ghatge MS, Safo MK. Hemoglobin: Structure, function and allostery. Vertebrate and invertebrate respiratory proteins, lipoproteins and other body fluid proteins. $2020: 345-82$.

5. Hopp MT, Domingo-Fernández D, Gadiya Y, Detzel MS, Schmalohr BF, Steinbock F, Imhof D, HofmannApitius $M$. Unravelling the debate on heme effects in COVID-19 infections. BioRxiv. 2020 Jan 1.

6. Tao Z, Xu J, Chen W, Yang Z, Xu X, Liu L, Chen R, Xie $\mathrm{J}$, Liu M, Wu J, Wang $H$. Anemia is associated with severe illness in COVID $\square$ 19: A retrospective cohort study. Journal of medical virology. 2021 Mar; 93(3):1478-88.

7. Cavezzi A, Troiani E, Corrao S. COVID-19: Hemoglobin, iron, and hypoxia beyond inflammation. A narrative review. Clinics and practice. 2020 May; 10(2):24-30.

8. Kucuk A, Cumhur Cure M, Cure E. Can COVID-19 cause myalgia with a completely different mechanism? A hypothesis. Clinical rheumatology. 2020 Jul; 39:2103-4.

9. Anai M, Akaike K, Iwagoe $\mathrm{H}$, Akasaka T, Higuchi T, Miyazaki A, Naito D, Tajima Y, Takahashi H, Komatsu T, Masunaga A. Decrease in hemoglobin level predicts increased risk for severe respiratory failure in COVID-19 patients with pneumonia. Respiratory Investigation. 2021 Mar 1; 59(2):187-93.

10. Nóbrega F, Mauad VA, Borducchi DM. Does COVID $\square 19$ really impact on the oxy $\square$ hemoglobin dissociation curve? eJHaem. 2020 Nov; 1(2):604-7.

11. Liu W, Li H. COVID-19: Attacks the 1-beta chain of hemoglobin and captures the porphyrin to inhibit heme metabolism. Am Chem Soc. 2020.

12. John Paul Graff. Blood analysis reveals a non-typical finding in viral infections. UC Davis Health, Newsroom, 2020. 
13. Yang M, Hon KL, Li K, Fok TF, Li CK. The effect of SARS coronavirus on blood system: Its clinical findings and the pathophysiologic hypothesis. Journal of Experimental Hematology. 2003 Jun 1; 11(3):217-21.

14. Hariyanto $\mathrm{TI}$, Kurniawan A. Anemia is associated with severe coronavirus disease 2019 (COVID-19) infection. Transfusion and Apheresis Science. 2020 Dec 1; 59(6).
15. Lippi G, Mattiuzzi C. Hemoglobin value may be decreased in patients with severe coronavirus disease 2019. Hematology, transfusion and cell therapy. 2020 Jun; 42(2):116-7.

\section{AUTHORSHIP AND CONTRIBUTION DECLARATION}

\begin{tabular}{|c|c|c|c|}
\hline Sr. \# & Author(s) Full Name & Contribution to the paper & Author(s) Signature \\
\hline 1 & Zunnera Rashid Chaudhry & $\begin{array}{l}\text { Design of the work, analysis, } \\
\text { interpretation of data of work, Final } \\
\text { approval of version to be published, } \\
\text { critical evaluation. }\end{array}$ & \\
\hline 2 & Sana Rasheed & $\begin{array}{l}\text { Drafting the work, Statistical } \\
\text { analysis, Interpretation of data of }\end{array}$ & \\
\hline 3 & Sabeen Shakir & $\begin{array}{l}\text { work. } \\
\text { Design, analysis and drafting the } \\
\text { work. }\end{array}$ & \\
\hline 4 & Erum Rashid & $\begin{array}{l}\text { Analysis, design of work } \\
\text { interpretation of data. }\end{array}$ & \\
\hline 5 & Maliha Ansari & Drafting and design of work, critical & \\
\hline 6 & & Design and drafting the work. & \\
\hline
\end{tabular}

